\title{
PENERAPAN PENDEKATAN SCIENTIFIC BERBASIS PEMBELAJARAN AKTIF SAME DIFFERENT UNTUK MENINGKATKAN HASIL BELAJAR SISWA MATERI POKOK PANCASILA SEBAGAI DASAR NEGARA DAN PANDANGAN HIDUP BANGSA MATA PELAJARAN PKN \\ ${ }^{1}$ Nurliyani \\ ${ }^{1}$ SMP Negeri 1 Situbondo \\ Email: nurliyani_112@gmail.com
}

Received: July 5, 2021 Revised: July 10, $2021 \quad$ Accepted: Augst 17, 2021

\begin{abstract}
ABSTRAK
Dalam proses belajar mengajar PKn di SMP Negeri 1 Situbondo, terutama kelas VIII-C selama ini yang telah dilaksanakan sebagian belum memenuhi KKM yang telah ditentukan. Contoh pada saat ulangan umum semester ganjil yang memenuhi KKM hanya 70\%. Minat belajar siswa semakin menurun karena sibuk main HP terutama pada malam hari tidak ingat belajar lagi, sehingga pada waktu proses pembelajaran berlansung ada yang mengantuk kurang memperhatikan dan kurang konsentrasi. Dengan adanya Metode Penerapan pendekatan scientific berbasis pembelajaran aktif same different diharapkan dapat meningkatkan aktivitas dan hasil belajar. Desain penelitian menggunakan PTK. Teknik pengumpulan data berupa observasi, wawancara, tes dan dokumentasi.
\end{abstract}

Kata Kunci $\quad$ : Pendekatan scientific, same different, Hasil Belajar

\section{PENDAHULUAN}

Di SMP Negeri 1 Situbondo sebagian besar siswa kurang motifasi dari orang tuanya, karena sibuk bekerja. Sehingga orang tua tidak sempat memperhatikan dan memantau perkembangan anakya. Selain itu proses pembelajaran lebih berorientasi pada penyelesaian materi pada buku dan guru belum menerapkan pembelajaran yang berhubungan dengan konteks lingkungan siswa keadaan ini membuat siswa relatif pasif selama pembelajaran berlangsung. Salah satu upaya untuk mewujudkan pembelajaran tersebut adalah menerapkan pembelajaran aktif dengan same different.

Strategi belajar aktif sangat banyak contoh yang dapat diterapkan diantaranya Every one is teacher here, Card Short, The power of two, Video critic, Snow Bowling Active debate dan the power of two serta Same Different. Dari beberapa contoh model pembelajaran aktif tersebut peneliti tertarik untuk pembelajaran aktif dengan same different, siswa mampu mengorganisasikan kelas dan dapat menjelaskan point-point penting dalam materi dan mengajukan serta menjawab pertanyaan yang berbeda sehingga dapat ditarik kesimpulan berdasarkan pertanyaan yang telah dibahas bersama dengan guru. 
Salah satu pendekatan yang bisa diterapkan untuk dapat meningkatkan aktivitas pembelajaran dan mengembangkan karakter siswa adalah dengan menggunakan pendekatan scientific. Guru sebagai ujung tombak yang secara langsung menghadapi siswa harus mampu menerapkan kurikulum yang berlaku. Kurangnya pemahaman guru terhadap kurikulum bisa berakibat fatal terhadap hasil belajar siswa, baik dari segi kognitif, afektif maupun psikomotornya. Sebelum nantinya akan menerapkan kurikulum 2013 yang menggunakan pendekatan scientific, guru harus memahami pendekatan scientific terlebih dahulu. Pendekatan scientific di dalam Modul Pelatihan Pendampingan

Bagi guru di SMP Negeri 1 Situbondo, hasil penelitian ini dapat menambah pengetahuan tentang strategi pembelajaran PKn yang tepat digunakan dalam pembelajaran. Bagi Siswa dapat dijadikan suatu cara untuk mengatasi kesulitan belajar siswa. Bagi peneliti selanjutnya, hasil penelitian ini dapat memberi masukan serta dapat dijadikan acuan untuk mengadakan penelitian sejenis, terutama dalam ruang lingkup yang lebih luas. Bagi Sekolah dapat dijadikan suatu masukan positif dalm meningkatkan prestasi belajar siswa

Pendekatan scientific dimaksudkan untuk memberikan pemahaman kepada siswa dalam mengenal, memahami berbagai materi menggunakan pendekatan ilmiah, sehingga siswa bisa memperoleh informasi dari mana saja, kapan saja, dan tidak bergantung pada informasi searah dari guru. Kondisi pembelajaran dengan menggunakan pendekatan scientific ini diharapkan dapat mendorong siswa dalam mencari tahu dari berbagai sumber melalui observasi, dan bukan hanya diberi tahu sehingga siswa dapat memperoleh pengalaman bermakna dari proses belajar yang diterimanya. Seperti yang dikemukakan Slameto (2010: 2) bahwa belajar merupakan suatu proses usaha yang dilakukan seseorang untuk memperoleh suatu perubahan tingkah laku yang baru secara keseluruhan, sebagai hasil pengalamannya sendiri dalam interaksi dengan lingkungannya.

Tujuan pembelajaran dengan pendekatan scientific yang didasarkan pada keunggulan pendekatan tersebut di dalam Modul Pelatihan Pendampingan Kurikulum 2013 (Kemendikbud, 2013: 1.2) adalah sebagai berikut. “(1) Untuk meningkatkan kemampuan intelek, khususnya kemampuan berpikir tingkat tinggi siswa, (2) untuk membentuk kemampuan siswa dalam menyelesaikan suatu masalah secara sistematik, (3) terciptanya kondisi pembelajaran dimana siswa merasa bahwa belajar itu merupakan suatu kebutuhan, (4) diperolehnya hasil belajar yang tinggi, (5) untuk melatih siswa dalam mengomunikasikan ide-ide, khususnya dalam menulis artikel ilmiah, (6) untuk mengembangkan karakter."

Adapun langkah-langkah pembelajaran dengan menggunakan pendekatan scientific dalam Lampiran IV Permendikbud Nomor 81A tentang pedoman umum 
pembelajaran, adalah sebagai berikut ini.

Metode mengamati mengutamakan kebermaknaan proses pembelajaran (meaningfull learning). Dengan metode observasi ini siswa dapat menemukan fakta bahwa ada hubungan antara obyek yang dianalisis dengan materi pembelajaran yang diberikan oleh guru. Dalam proses mengamati ini, siswa melibatkan seluruh panca indera yang dimilikinya. Hal ini sesuai dengan yang dikemukakan Winarni (2012: 21), bahwa keterampilan mengobservasi merupakan keterampilan yang dikembangkan dengan menggunakan panca indera dan alat bantu indera untuk memperoleh informasi serta mengidentifikasi nama atau karakteristik dari suatu objek atau kejadian yang diamati. Metode ini memiliki keunggulan tertentu, seperti menyajikan media obyek secara nyata maupun melalui media, siswa senang dan tertantang, dan mudah pelaksanaannya. Metode mengamati sangat bermanfaat bagi pemenuhan rasa ingin tahu siswa, sehingga proses pembelajaran memiliki kebermaknaan yang tinggi.

Kegiatan mengamati dalam pembelajaran sebagaimana dikemukakan dalam Lampiran IV Permendikbud Nomor 81A (2013: 13), guru membuka secara luas dan bervariasi kesempatan siswa untuk melakukan pengamatan melalui kegiatan melihat, menyimak, mendengar, dan membaca. Guru memfasilitasi siswa untuk melakukan pengamatan, melatih mereka untuk memperhatikan (melihat, membaca, mendengar) hal yang penting dari suatu benda atau objek.

Adapun fungsi bertanya dalam Modul Pelatihan Implementasi Kurikulum 2013 (Kemendikbud, 2013: 212) adalah sebagai berikut. “(1) Membangkitkan rasa ingin tahu, minat, dan perhatian siswa tentang suatu tema atau topik pembelajaran, (2) mendorong dan menginspirasi siswa untuk aktif belajar, serta mengembangkan pertanyaan dari dan untuk dirinya sendiri, (3) mendiagnosis kesulitan belajar siswa sekaligus menyampaikan rencana untuk mencari solusinya, (4) membangkitkan keterampilan siswa dalam berbicara, mengajukan pertanyaan, dan memberi jawaban secara logis, sistematis, dan menggunakan bahasa yang baik dan benar, (5) mendorong partisipasi siswa dalam berdiskusi, beragumen, mengembangkan kemampuan berpikir, dan menarik kesimpulan, (6) membiasakan siswa berpikir spontan dan cepat, serta sigap dalam merespon persoalan yang tiba-tiba muncul, (7) melatih kesantunan dalam berbicara dan membangkitkan kemampuan berempati satu sama lain.”

Kegiatan mengumpulkan informasi merupakan tindak lanjut dari kegiatan bertanya. Kegiatan ini dilakukan dengan menggali dan mengumpulkan informasi dari berbagai sumber melalui berbagai cara. Untuk itu siswa dapat membaca buku atau sumber yang lebih banyak, dan memperhatikan fenomena atau objek dengan lebih teliti. Dari kegiatan tersebut terkumpul sejumlah informasi. Dalam Lampiran IV Permendikbud 
Nomor 81A (2013: 13), aktivitas mengumpulkan informasi dilakukan melalui eksperimen, membaca sumber lain selain buku teks, mengamati objek atau kejadian, aktivitas wawancara dengan narasumber dan sebagainya.

Mengkomunikasikan adalah menyampaikan hasil pengamatan yang berhasil dikumpulkan atau menyampaikan hasil penyelidikan, yang dapat dikembangkan dengan cara menghimpun informasi dari grafik atau gambar yang menjelaskan objek secara rinci (Winarni, 2012: 144-145). Kegiatan ini dapat dilakukan melalui menuliskan atau menceritakan apa yang ditemukan dalam kegiatan mencari informasi, mengasosiasikan dan menemukan pola. Hasil tersebut disampikan di kelas dan dinilai oleh guru sebagai hasil belajar siswa atau kelompok siswa tersebut. Kegiatan mengkomunikasikan dalam kegiatan pembelajaran sebagaimana disampaikan dalam Lampiran IV Permendikbud Nomor 81A (2013: 14), adalah menyampaikan hasil pengamatan, kesimpulan berdasarkan hasil analisis secara lisan, tertulis, atau media lainnya.

Salah satu yang harus dilakukan adalah dengan mengaktifkan belajar siswa (active learning). Ketika belajar siswa aktif, siswa lebih banyak bekerja. Mereka mempergunakan otak mereka, belajar ide-ide baru, pemecahan masalah, dan menerapkan apa yang mereka pelajari. Lebih dari itu, belajar aktif menjadi penting sebab untuk belajar sesuatu, siswa perlu mendengar, melihat, bertanya, dan mendiskusikannya dengan yang lain.

Strategi pembelajaran aktif Same Different merupakan sebuah strategi yang mudah, guna memperoleh partisipasi kelas yang keseluruhan dan tanggung jawab secara individu. Strategi ini memberikan kesempatan pada setiap peserta didik untuk bertindak menjelaskan perbedaan dan persamaan dari masalah yang diajukan oelh guru dan hasil penemuan siswa berdasarkan hasil diskusi kelompok terhadap peserta didik lain. Dengan strategi ini, peserta didik yang selama ini tidak mau terlibat akan ikut serta dalam pembelajaran secara aktif.

Prosedur dari strategi ini adalah:

1. Membuat pertanyaan;

2. Memberitahu topik;

3. Meminta siswa mencari informasi;

4. Meminta tim untuk menjelaskan jawabannya dikelas besar

5. setiap siswa memberikan penjelasan tentang persamaan dan perbedaan pada gambar yang guru sajikan 
Kemampuan-kemampuan tersebut mencakup aspek kognitif, afektif, dan psikomotorik. Hasil belajar dapat dilihat melalui kegiatan evaluasi yang bertujuan untuk mendapatkan data pembuktian yang akan menunjukkan tingkat kemampuan siswa dalam mencapai tujuan pembelajaran. Hasil belajar yang diteliti dalam penelitian ini adalah hasil belajar kognitif PKn yang mencakup tiga tingkatan yaitu pengetahuan (C1), pemahaman (C2), dan penerapan (C3). Instrumen yang digunakan untuk mengukur hasil belajar siswa pada aspek kognitif adalah tes.

Guru dalam proses belajar mengajar selalu bertujuan agar materi yang disampaikan dapat dikuasai siswa dengan sebaik-baiknya. Akan tetapi harapan itu belum dapat diwujudkan sepenuhnya, karena pembelajaran yang masih berlangung selama ini hanya mementingkan hasilnya saja, tidak mementingkan prosesnya. Salah satu metode pembelajaran yang dapat meningkatkan penguasaan materi siswa secara penuh dalam pembelajaran adalah dengan Strategi pembelajaran aktif Same Different. Dalam metode ini siswa diharapkan dapat menguasai setiap unit bahan pelajaran baik secara perseorangan maupun kelompok atau dengan kata lain penguasaan penuh, sehingga metode ini diharapkan dapat meningkatkan hasil belajar siswa. Dari uraian di atas secara skematis dapat dijelaskan sebagai berikut:

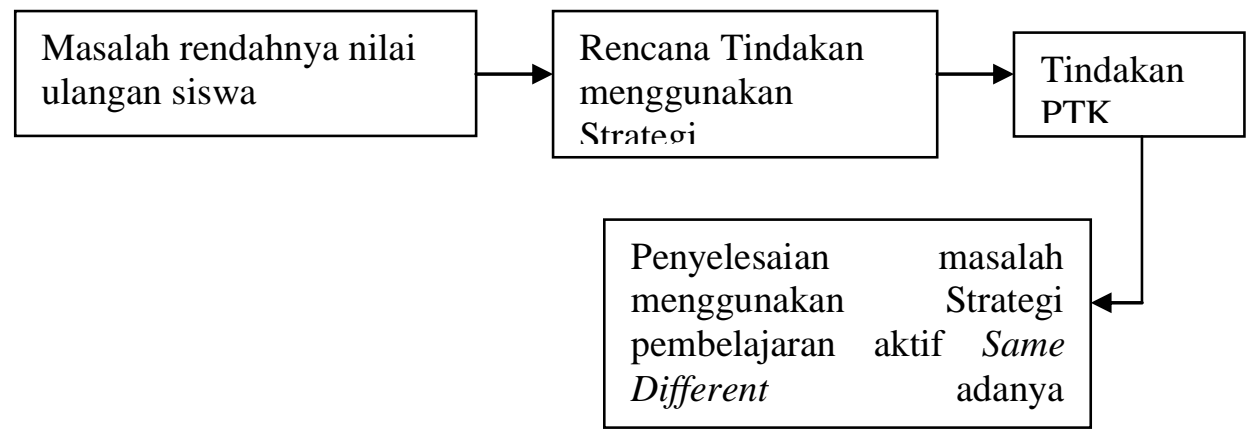

Kegiatan yang dilakukan dalam tahap perencanaan ini adalah sebagai berikut:

1. Menyusun rencana pembelajaran pada pokok bahasan memahami materi yang akan dibahas

2. Mempersiapkan materi berupa pokok bahasan pancasila sebagai dasar negara dan pandangan hidup bangsa dan mempersiapkan contoh pancasila sebagai dasar negara dan pandangan hidup bangsa

3. Mempersiapkan soal sebagai bahan diskusi di dalam kelas

4. Mempersiapkan soal tes ulangan harian untuk siswa

5. Mempersiapkan tugas pekerjaan rumah untuk siswa

6. Mempersiapkan rangkuman materi untuk dibagikan kepada siswa 
7. Proses belajar mengajar dibagi menjadi tiga tahap yaitu (a) Pendahuluan, guru memberikan apersepsi tentang pentingnya pembelajaran PKn yang akan dibahas; (b) Kegiatan inti, guru mendampingi dan membimbing siswa dalam melakukan kegiatan pendekatan scientific berbasis pembelajaran aktif same different. Kegiatan pendekatan scientific berbasis pembelajaran aktif same different dimulai dari siswa menjelaskan materi analisis materi yang berkaitan dengan pemahaman konsep atau pengertian dari pancasila sebagai dasar negara dan pandangan hidup bangsa, Mengorganisasikan siswa ke dalam kelompok belajar, dan diskusi untuk mencapai pengambilan kesimpulan; (c) Kegiatan penutup.

8. Mempersiapkan daftar pertanyaan untuk mewawancarai siswa mengenai tanggapannya terhadap pendekatan scientific berbasis pembelajaran aktif same different.

9. Membuat lembar observasi yang digunakan peneliti untuk mengamati motivasi dan hasil belajar siswa.

Pada tahap ini kegiatan yang dilaksanakan adalah melakukan tindakan berdasarkan pada perencanaan yang telah dibuat. Peneliti bertindak sebagai guru. Penelitian ini dilakukan dalam dua siklus dengan rincian sebagai berikut:

\section{Siklus 1}

a. Kegiatan pendahuluan

Guru memberikan apersepsi kepada siswa sesuai dengan materi yang akan dibahas.

b. Kegiatan Inti

Pada kegiatan ini peneliti menerapkan kegiatan pendekatan scientific berbasis pembelajaran aktif same different yang terdiri dari analisis materi yang berkaitan dengan pemahaman konsep atau pengertian dari pancasila sebagai dasar negara dan pandangan hidup bangsa, mengorganisasikan siswa ke dalam kelompok belajar, dan diskusi untuk mencapai pengambilan kesimpulan dengan langkah-langkah sebagai berikut:

Langkah I: Analisis contoh pancasila sebagai dasar negara dan pandangan hidup bangsa yang berkaitan dengan pemahaman konsep atau pengertian dari pancasila sebagai dasar negara dan pandangan hidup bangsa

Langkah II : $\quad$ Membagi siswa menjadi beberapa kelompok untuk bertatap muka atau berdiskusi. Dalam satu kelompok terdiri dari dua orang siswa. Kegiatan ini termasuk unsur bertatap muka dalam pembelajaran kooperatif dan siswa memperhatikan dan mencatat penjelasan guru dan guru memberi lembar tugas pemahaman materi 
Langkah III : Membuat pertanyaan berdasarkan masalah yang diajukan melalui gambar;

Langkah IV : Memberitahu topik;

Langkah V : Meminta siswa mencari informasi;

Langkah VI : Meminta tim untuk menjelaskan jawabannya dikelas besar

Langkah VII : setiap siswa memberikan penjelasan tentang persamaan dan perbedaan pada gambar yang guru sajikan

Langkah VIII: Pengambilan Kesimpulan

Guru bersama siswa menyimpulkan materi yang dibahas saat itu sampai siswa dan guru dapat memahami tujuan pelajaran yang dibahas.

c. Kegiatan penutup

Guru memberikan tugas pelajaran rumah.

\section{Siklus 2}

Jenis tes yang digunakan dalam penelitian ini adalah post test untuk mengetahui tingkat keberhasilan siswa setelah menerapkan pendekatan scientific berbasis pembelajaran aktif same different.

Analisis data dalam penelitian ini adalah deskriptif kualitatif yaitu berusaha memaparkan proses pendekatan scientific berbasis pembelajaran aktif same different. Ketuntasan belajar siswa sebesar $80 \%$ atau lebih, maka dikatakan berhasil atau tercapai tujuan yang diinginkan untuk mencari prosentase ketuntasan belajar siswa secara klasikal digunakan rumus:

$$
\begin{gathered}
\mathrm{P}=\frac{n}{N} \times 100 \% \\
\mathrm{P}=\text { Prosentase Ketuntasan } \\
\mathrm{n}=\text { Jumlah Siswa Yang Tuntas } \\
\mathrm{N}=\text { Jumlah Seluruh Siswa }
\end{gathered}
$$

Setelah nilai hasil belajar dipresentasikan dan dicari standar ketuntasan untuk mengetahui daya serap siswa secara individu dan klasikal standar tersebut yaitu:

1. Daya serap perseorangan

Seorang siswa dikatakan telah memenuhi standar ketuntasan belajar bila mencapai nilai $\geq 70$. 
2. Daya serap klasikal

Suatu kelas dikatakan telah memenuhi standar ketuntasan belajar di kelas tersebut telah mencapai $\geq 85 \%$ dari jumlah siswa yang telah mencapai nilai $\geq 70$.

Berdasarkan penjelasan di atas bahwa KKM di pendekatan scientific berbasis pembelajaran aktif same different yaitu 70 untuk daya serap perorangan dan daya serap klasikal yaitu $85 \%$.

Hasil observasi peneliti dapat dilihat pada tabel 4.1 sebagai berikut:

Tabel 4.1 Nilai Prasiklus

\begin{tabular}{|l|c|c|}
\hline \multicolumn{1}{|c|}{ Nilai } & Jumlah Siswa & Persentase \\
\hline Siswa Tuntas $(\geq 70)$ & 16 & $50 \%$ \\
\hline Siswa Tidak Tuntas $(<70)$ & 16 & $50 \%$ \\
\hline Jumlah & 32 & $100 \%$ \\
\hline
\end{tabular}

Gambar 4.1 Persentase Prasiklus

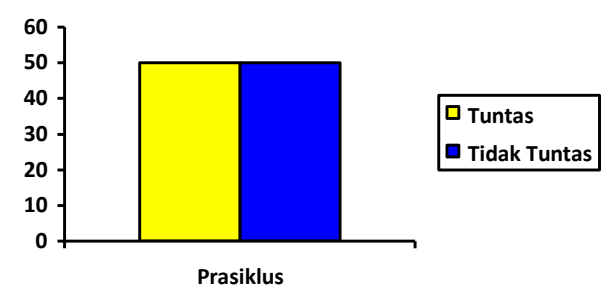

Kegiatan yang dilakukan pada tahap perencanaan ini adalah melaksanakan kegiatan sesuai dengan desain yang telah dibuat sebelumnya (seperti yang dijelaskan pada Bab III). Pada tahap ini semua persiapan yang telah dilakukan, setelah dilakukan diskusi antara guru, peneliti dan observer, baik yang berkaitan dengan persiapan mengajar (menyusun Silabus, RPP, Soal dan kunci jawaban) maupun persiapan lainnya meliputi membuat panduan observasi, mengajukan siswa yang akan dibentuk kelompok kecil.

\section{Pelaksanaan Tindakan}

Pertemuan Pertama

Pelaksanaan pertemuan pertama ini sudah mulai menggunakan Pendekatan scientific berbasis pembelajaran aktif same different pada materi pokok pancasila sebagai dasar negara dan pandangan hidup bangsa. Adapun langkah-langkah yang diambil oleh guru dengan dibantu oleh peneliti dalam menerapkan Pendekatan scientific berbasis pembelajaran aktif same different pada pertemuan pertama adalah sebagai berikut:

1) Kegiatan pendahuluan

a) Guru memberikan apersepsi kepada siswa sesuai dengan materi yang akan dibahas 
2) Kegiatan Inti

a) Siswa dibagi dalam suatu kelompok-kelompok.

b) Guru menganalisis contoh pancasila sebagai dasar negara dan pandangan hidup bangsa yang berkaitan dengan pemahaman konsep atau pengertian dari pancasila sebagai dasar negara dan pandangan hidup bangsa.

c) Guru membuat pertanyaan berdasarkan masalah yang diajukan melalui gambar

d) Guru memberitahu topik.

e) Guru meminta siswa mencari informasi untuk mengetahui perbedaan dan persamaan.

f) Guru meminta tim untuk menjelaskan jawabannya dikelas besar.

g) setiap siswa memberikan penjelasan tentang persamaan dan perbedaan pada gambar yang guru sajikan

h) Siswa selesai bicara, siswa lain memikirkan cara lain untuk melanjutkan diskusi.

i) Pada akhir diskusi kelompok diadakan refleksi.

3) Kegiatan penutup

a. Guru bersama siswa Presentasi Hasil berdasarkan chips yang dijelaskan oleh siswa melalui presentasi siswa.

b. Guru memberikan tugas pelajaran rumah, pemberian tugas dimaksudkan untuk menyeimbangkan pengetahuan

Pelaksanaan pertemuan pertama siswa yang ditunjuk menentukan anggota kelompok. Siswa masih merasa agak kaku dengan lingkungan kelompok yang kurang kondusif. Namun pada kesempatan siswa untuk berfikir kreatif pada saat mengerjakan soal-soal yang diberikan guru. Siswa saling menukar jawaban untuk dikoreksi dengan bimbingan guru, hal ini dilakukan untuk meningkatkan hasil belajar.

\section{Pertemuan Kedua}

Pelaksanaan pertemuan kedua ini mengacu pada mengidentifikasi bentuk pancasila sebagai dasar negara dan pandangan hidup bangsa .

Kegiatan pendahuluan

a) Guru memberikan apersepsi kepada siswa sesuai dengan materi yang akan dibahas

Kegiatan Inti

a) Siswa dibagi dalam suatu kelompok-kelompok (tanggung jawab)

b) Guru menganalisis contoh pancasila sebagai dasar negara dan pandangan hidup bangsa yang berkaitan dengan pemahaman konsep atau pengertian dari pancasila sebagai dasar negara dan pandangan hidup bangsa.(teliti) 
c) Guru membuat pertanyaan berdasarkan masalah yang diajukan melalui gambar (mandiri)

d) Guru memberitahu topik. (rasa ingin tahu)

e) Guru meminta siswa mencari informasi untuk mengetahui perbedaan dan persamaan (tanggung jawab)

f) Guru meminta tim untuk menjelaskan jawabannya dikelas besar (tanggung jawab)

g) setiap siswa memberikan penjelasan tentang persamaan dan perbedaan pada gambar yang guru sajikan

h) Siswa selesai bicara, siswa lain memikirkan cara lain untuk melanjutkan diskusi (tanggung jawab)

i) Pada akhir diskusi kelompok diadakan refleksi.

Kegiatan penutup

a) Guru bersama siswa Presentasi Hasil berdasarkan chips yang dijelaskan oleh siswa melalui presentasi siswa. (mandiri)

b) Guru memberikan tugas pelajaran rumah, pemberian tugas dimaksudkan untuk menyeimbangkan pengetahuan.

Hasil observasi pada siklus 1 bahwa mencapai ketuntasan secara klasikal mencapai $75 \%$ atau 24 siswa yang tuntas. Nilai rata-rata hasil belajar mencapai 70 sehingga perlu adanya siklus 2 tidak hanya mencapai ketuntasan secara klasikal, hasil belajar siswa pada siklus 1 dapat dilihat pada tabel 4.2 sebagai berikut:

Tabel 4.2 Nilai Siklus 1

\begin{tabular}{|l|c|c|}
\hline \multicolumn{1}{|c|}{ Nilai } & Jumlah Siswa & Persentase \\
\hline Siswa Tuntas $(\geq 70)$ & 24 & $75 \%$ \\
\hline Siswa Tidak Tuntas $(<70)$ & 8 & $25 \%$ \\
\hline Jumlah & 26 & $100 \%$ \\
\hline
\end{tabular}

\section{Gambar 4.2 Persentase Siklus 1}

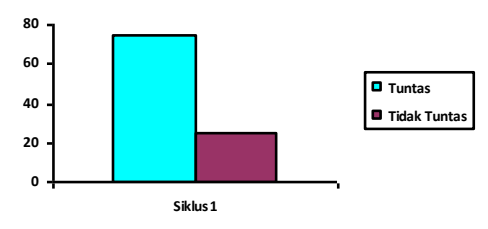

Hasil belajar pada siklus 1 ketuntasan belajar siswa kelas VIII-C yaitu secara klasikal mencapai $75 \%$ atau 24 siswa yang tuntas dan siswa yang belum tuntas 8 siswa atau $25 \%$. Hasil observasi hasil belajar siswa mencapai ketuntasan $75 \%$ dan perlu 
diadakan siklus 2 karena masih belum mencapai ketuntasan klasikal sesuai yang ditetapkan oleh sekolah. Guru dalam hal ini sebagai peneliti dalam menyampaikan tujuan pembelajaran sudah dilaksanakan dengan baik, guru/peneliti dalam kemampuan mengorganisir siswa dalam kelompok belajar (membentuk kelompok) juga sudah dilaksanakan dengan baik, guru/peneliti dalam membimbing siswa dalam persiapan kegiatan pembelajaran kurang terlaksana dengan baik, guru/peneliti membimbing siswa untuk membaca kembali buku pelajaran kurang terlaksana dengan baik dan guru/peneliti dalam menunjukkan contoh artikel yang berhubungan dengan materi juga belum terlaksana dengan baik.

Guru membimbing siswa untuk membaca kembali buku pelajaran. Guru kurang meminta siswa untuk membaca kembali untuk menemukan jawaban atau masalah yang sebenarnya pada pancasila sebagai dasar negara dan pandangan hidup bangsa.

Tabel 4.3

Rekapitulasi Prasiklus dan Siklus 1

\begin{tabular}{|c|c|c|c|c|c|}
\hline \multirow{3}{*}{ Nilai } & \multicolumn{4}{|c|}{ Siklus } & \multirow{3}{*}{ Peningkatan } \\
\hline & \multicolumn{2}{|c|}{ Prasiklus } & \multicolumn{2}{|c|}{ Siklus 1} & \\
\hline & \multicolumn{2}{|c|}{ Jumlah/Prosentase } & \multicolumn{2}{|c|}{ Jumlah/Prosentase } & \\
\hline$\geq 70$ & 16 & $50 \%$ & 24 & $75 \%$ & \multirow{2}{*}{$25 \%$} \\
\hline$<70$ & 16 & $50 \%$ & 8 & $25 \%$ & \\
\hline
\end{tabular}

\section{Penelitian Siklus 2}

Kegiatan yang dilakukan pada tahap perencanaan ini adalah melaksanakan kegiatan sesuai dengan desain yang telah dibuat sebelumnya (seperti yang dijelaskan pada siklus 1), pada tahap ini semua persiapan telah dilakukan setelah dilakukan diskusi antara guru, peneliti dan observer, baik yang berkaitan dengan persiapan mengajar (menyusun rencana pembelajaran pada Pokok Bahasan yang akan dibahas, gambar dan perlengkapan dalam Pokok Bahasan yang akan dibahas, soal sebagai bahan diskusi baik diluar kelas maupun di dalam kelas dan kunci jawaban serta mempersiapkan deskriptif tugas tim peneliti.

\section{Pelaksanaan Tindakan}

\section{Pertemuan Ketiga}

Kegiatan pendahuluan, guru memberikan apersepsi kepada siswa sesuai dengan materi yang akan dibahas

Kegiatan Inti

a) Siswa dibagi dalam suatu kelompok-kelompok 
b) Siswa memiliki pemahaman konsep atau pengertian dari pancasila sebagai dasar negara dan pandangan hidup bangsa.

c) Siswa mampu mengajukan masalah yang diajukan melalui gambar

d) Guru memberitahu topik.

e) Siswa mencari informasi untuk mengetahui perbedaan dan persamaan

f) Siswa menjelaskan jawabannya dikelas besar

g) setiap siswa memberikan penjelasan tentang persamaan dan perbedaan pada gambar yang guru sajikan

h) Siswa selesai bicara, siswa lain memikirkan cara lain untuk melanjutkan diskusi

i) Pada akhir diskusi kelompok diadakan refleksi.

Kegiatan penutup

a) Siswa menarik kesimpulan berdasarkan chips yang dijelaskan oleh siswa melalui presentasi siswa. (mandiri)

b) Guru memberikan tugas pelajaran rumah, pemberian tugas dimaksudkan untuk menyeimbangkan pengetahuan. (jujur)

\section{Pertemuan Keempat}

Kegiatan pendahuluan, guru memberikan apersepsi kepada siswa sesuai dengan materi yang akan dibahas

Kegiatan Inti

a) Siswa dibagi dalam suatu kelompok-kelompok

b) Siswa memiliki pemahaman konsep atau pengertian dari pancasila sebagai dasar negara dan pandangan hidup bangsa.

c) Siswa mampu mengajukan masalah yang diajukan melalui gambar

d) Guru memberitahu topik.

e) Siswa mencari informasi untuk mengetahui perbedaan dan persamaan

f) Siswa menjelaskan jawabannya dikelas besar

g) setiap siswa memberikan penjelasan tentang persamaan dan perbedaan pada gambar yang guru sajikan

h) Siswa selesai bicara, siswa lain memikirkan cara lain untuk melanjutkan diskusi

i) Pada akhir diskusi kelompok diadakan refleksi.

Kegiatan penutup

Siswa menarik kesimpulan berdasarkan chips yang dijelaskan oleh siswa melalui presentasi siswa. Guru memberikan tugas pelajaran rumah, pemberian tugas dimaksudkan untuk menyeimbangkan pengetahuan.

Kegiatan ketiga dan keempat sama dalam siklus 2 guru lebih membimbing siswa untuk mampu menjelaskan materi kepada siswa lain dengan percaya diri. Maka dalam hal 
ini peneliti tidak menjelaskan secara detail kembali tentang pertemuan keempat siklus 2 tersebut.

Secara garis besar ulangan atau pelaksanaan tes pada siklus 1 berjalan dengan lancar dan tertib. Hasil belajar pada siklus 2 mencapai ketuntasan secara klasikal sebesar 91\% atau sebanyak 29 siswa. Dapat dilihat pada tabel berikut:

Tabel 4.4 Rekapitulasi Hasil Belajar Kognitif Prasiklus, Siklus 1 dan Siklus 2

\begin{tabular}{|l|c|c|c|c|c|c|}
\hline \multirow{2}{*}{ Nilai } & \multicolumn{2}{|c|}{ Prasiklus } & \multicolumn{2}{c|}{ Siklus 1 } & \multicolumn{2}{c|}{ Siklus 2 } \\
\cline { 2 - 6 } & \multicolumn{2}{|c|}{ Jumlah/Prosentase } & \multicolumn{2}{c|}{ Jumlah/Prosentase } & \multicolumn{2}{c|}{ Jumlah/Prosentase } \\
\hline$\geq 70$ & 16 & $50 \%$ & 24 & $75 \%$ & 29 & $91 \%$ \\
\hline$<70$ & 16 & $50 \%$ & 8 & $25 \%$ & 3 & $9 \%$ \\
\hline
\end{tabular}

Hasil observasi terhadap guru pada siklus 2 yang dilakukan oleh peneliti dalam pembelajaran menunjukkan, aktivitas guru sebagai fasilitator kekurangan dalam siklus 1 sudah teratasi berkat kerjasama tim peneliti. Guru memberikan semangat, penguatan dan pengakuan atas usaha siswa dalam pembelajaran, baik dalam membimbing siswa kepada siswa saat mengalami kesulitan menyelesaikan soal.

\section{PEMBAHASAN}

Pada hasil belajar siswa pada siklus 2 sudah mengalami peningkatan dari siklus sebelumnya, meskipun peningkatannya tidak terlalu tinggi dikarenakan dalam mengerjakan tugas kurang teliti.

Peningkatan hasil belajar siswa menunjukkan bahwa penerapan Pendekatan scientific berbasis pembelajaran aktif same different dapat dipertimbangkan sebagai pendekatan pembelajaran yang baik diterapkan pada mata pelajaran PKn yang sangat berkaitan dengan kehidupan sehari-hari. Keunggulan pembelajaran dengan menggunakan penerapan Pendekatan scientific berbasis pembelajaran aktif same different pada penerapannya yang melibatkan siswa secara aktif dalam proses belajar mengajar dan mendorong siswa untuk memperoleh pengetahuannya sendiri tanpa selalu tergantung pada guru, meningkatkan konsentrasi dan pengetahuan siswa melalui pembelajaran yang bersifat afektif.

Bahwa dapat disimpulkan sebagai berikut:

1. Penerapan pendekatan scientific berbasis pembelajaran aktif same different materi pokok pancasila sebagai dasar negara dan pandangan hidup bangsa mata pelajaran PPKn Kelas VIII-C di SMP Negeri 1 Situbondo Tahun Pelajaran 2018/2019 sangat efektif. 
2. Penerapan pendekatan scientific berbasis pembelajaran aktif same different dapat meningkatkan hasil belajar siswa mencapai $16 \%$ materi pokok pancasila sebagai dasar negara dan pandangan hidup bangsa mata pelajaran PPKn Kelas VIII-C di SMP Negeri 1 Situbondo Tahun Pelajaran 2018/2019.

\section{DAFTAR PUSTAKA}

Gagne. 2005. Essentials of learning for instruction. Boston

Jamaris. 2006. Psikologi Belajar. Jakarta: Raja Grafindo Persada

Mudjiono. 2000. Interaksi dan Motivasi Belajar Mengajar.Jakarta: Rajawali

Muhibbin, 2003. Model Pembelajaran Menciptakan Proses Belajar Mengajar yang Kreatif dan Efektif. Jakarta, Bumi Aksara

Nasution. 2007. Mencari strategi pengembangan pendidikan nasional menjelang abad XXI. Jakarta: Grasindo

Ningtiash. 2007. Dasar-Dasar Kependidikan. Jakarta: Ditjen Bimbaga Islam

PGSM. 2007. [online]. Tersedia: http://meipanda.blogspot.com/2013/05/strukturpendukung-keanekaragaman.html

Purwanti. 2006. Psikologi pendidikan: Materi pendidikan bimbingan konseling di Perguruan Tinggi. Yogyakarta: Depdikbud

Sanjaya. 2008. Psikologi Pendidikan Jakarta PT. Rineka Cipta

Sardiman. 2003. Belajar dan faktor-faktor yang mempengaruhinya. Jakarta: PT Rineka cipta

Syaiful Bahri Djamarah. 2003. Psikologi Pendidikan Jakarta PT. Rineka Cipta

Sudjana. 2000. Metode dan teknik pembelajaran partisipatif. Jakarta: Falah Production

Sudjana. 2005. Psikologi Pendidikan dengan pendekatan Baru. Bandung: PT Remaja Rosdakarya

Suprayekti. 2003. Proses belajar Mengajar. Jakarta : PT.Bumi Aksara

Tabrani dkk. 2002. Psikologi pendidikan II. Jakarta:FEUI

Trinandita. 2004. Evaluasi diri demi peningkatan mutu pendidikan. Jakarta: Grasindo Zaini. 2008. Cooperative Learning. Yogyakarta: Pustaka Belajar 